\title{
Production Analysis of Bakso Based on The HACCP Method to Support Food Quality Control Courses
}

\author{
Rina Rifqie Mariana, Laili Hidayati, Soenar Sukopitojo \\ Culinary Education Study Program \\ Universitas Negeri Malang \\ Malang, Indonesia \\ rina.rifqie.ft@um.ac.id
}

\begin{abstract}
This research aimed at analyzing the production process of meatballs based on the HACCP method to manage food safety in an integrated manner from raw material selection, raw material storage, material processing, processed material storage, product distribution, and presentation. The research findings can be used as a reference for formulating the course materials for Food Quality Control. This study was conducted at two popular bakso producers in Malang with more than 200 franchises spread in 15 provinces in Indonesia. The data were gathered through direct and careful observation of the entire production process and followed up with interview and documentation. The data analysis was done systematically through data reduction, data display, verification, and conclusion drawing. The research results indicate that, overall, the entire production process in the two bakso restaurants has followed the correct and proper procedure. However, there are some critical points or manufacturing faults that can cause food contamination, such as inappropriate storage temperature, incorrect shipping method, and improper way of presentation. As a follow up to this research, it is necessary to conduct further studies in accordance with the HACCP Method, i.e. analysis of hazards, identification of the Critical Control Points, and other steps up to the documentation stage.
\end{abstract}

Keywords-production analysis, bakso, HACCP

\section{INTRODUCTION}

Bakso or meatball soup is a universal food in Indonesia. In its 34 provinces, bakso has always been a favourite snack from the young to the elderly. Not only in Indonesia, but meatball products made from restructured meat are also popular in other parts of the world, particularly Asia and some countries in Europe. For instance, meatballs with lime from Germany, Swedish meatballs, koefte from Turky, nunh hoa from Vietnam, curried kofter from India and Chinese meatballs [1][4]. Bowls of bakso sold in restaurants or street vendors in Indonesia always get a positive response from the community, and the most popular bakso is originated from Malang city of East Java known as bakso Malang. There are currently 525 street vendors selling that typical meatball soup in Malang city-excluding bakso sold in restaurants and permanent stalls - that are always crammed with consumers, especially high school students.
Nowadays, the role of consumer characteristics seems to be a major factor in establishing a food business. Moreover, in developing countries, more and more consumers are beginning to realize the importance of food safety. Several studies found that food nutrition, health and safety are key considerations to consumers in purchasing food [5], [6]. Hoek et al. [7], further pointed out that, in general, more consumers prefer healthy and sustainable food choices. In addition to health consideration, taste is another important factor that consumers take into account. Delicious Bakso, judging from the taste of meatballs and broth, is most consumers' favourite. Malang city with bakso as its centrepiece should be able to maintain and even increase consumer trust in this food. Through HACCP (Hazard Analysis and Critical Control Points) certification, the quality of meatballs can be ensured whether or not they have satisfied the standards of food safety.

Consumer trust in bakso may be declining because many research findings indicate that many meatballs in the market contain additional ingredients that endanger human health such as borax, formalin, and other harmful substances including microbiological contaminants due to errors in the production, distribution and presentation process [8]-[10]. People, sooner or later, may stop buying bakso if this safety issue is not dealt properly. Therefore, further research, such as using the HACCP method, needs to be conducted to enhance food safety management and product quality. Through HACCP, a prototype of safe and healthy meatballs can be produced. Also, the result of this quality assurance system can be used as a guideline for meatball producers to ensure the safety, quality and nutritional value of their products.

HACCP is a trusted preventive system that aims to ensure food safety by identifying specific hazards from microbial, chemical, and physical contamination; it is a control system, not a final product analysis [11]-[13]. HACCP can be regarded as a dynamic system that can eliminate potentially hazardous substances. The emergence of pathogens that cause food poisoning is due to changes in habits and consumption patterns [14]. HACCP is also recognized in the international food safety community as a global guideline for controlling the hazards in food manufacturing [15], [16]. Its traceability system provides a set of data on handling food retail and grocery industry along 
the supply chain. It is useful to identify and track product hazards at any point in the food processing chain [17]. In today's global marketing environment, producers should guarantee their food products to be safe and free from microbiological, chemical, and physical contamination. As happened to the salmon bread products supplied from a factory in eastern Hokkaido proven to be contaminated during the production process, resulting in all consumers abandoned the products [18]; a case like this usually makes a company goes bankrupt. The identification of hazards through HACCP should be considered and performed in the food production to prevent biological, chemical, and physical contaminants. Some researchers have studied in depth the impact of the implementation of HACCP on the quality of food products [19]-[22].

There are several steps to identify hazards and establish critical points based on the HACCP method. The very first step is to investigate how meatball producers undertake the production process. By doing so, it is easier to identify food safety hazards and give directions to producers for producing safe and healthy food. Students of the Associate's Degree (D3) in Gastronomy are taught to be entrepreneurs who truly understand food health and wellness, and safe steps in culinaryrelated operations, particularly the production of traditional Indonesian dishes.

\section{RESEARCH METHODS}

This research was conducted at two bakso restaurants in Malang city, Indonesia. These restaurants were selected because they are very popular among residents and domestic tourists craving for the typical bakso Malang. To increase consumer trust in the two restaurants, an HACCP certification is suggested to be conducted. Prior to that, however, production analysis should be done to determine which critical points that need improvement. By doing the production analysis in this study, the researchers could analyse potential microbiological, chemical and physical contamination in the production process - from raw material selection, raw material storage, material processing, processed material storage, product distribution, and presentation. The data were collected through direct and careful observation of the entire production process, and then recorded systematically based on the HACCP concept supported by interviews and documents.

\section{RESULTS AND DISCUSSION}

The application of HACCP in bakso Malang products aimed at preventing the occurrence of hazards, minimising health risks associated with the consumption of meatballs, and increasing consumer trust in food security. In fact, consumer trust has an indirect impact on trade promotion and business stability. The results of observations supported by interviews are shown in Table 1.

TABLE I. Meatball Production Process

\begin{tabular}{|c|c|c|c|}
\hline Processing & Bakso Restaurant A & Bakso Restaurant B & $\begin{array}{c}\text { Correct Raw Material Selection } \\
\text { and Processing }\end{array}$ \\
\hline $\begin{array}{ll}\text { Raw } & \text { Material } \\
\text { Selection } & \end{array}$ & $\begin{array}{l}\text { Beef cuts used for meatballs are the top } \\
\text { blade to round section. The broth is } \\
\text { made with rib bones. } \\
\text { Beef is bought from slaughterhouse at } 3 \\
\text { am. } \\
\text { A certain brand of tapioca flour in a } \\
\text { plastic package of } 250 \text { gr is used. It has } \\
\text { an expiry date and permit from Ministry } \\
\text { of Health, and hence feasible and safe to } \\
\text { use. It is not used after the expiration } \\
\text { date. This flour is used as a filler in } \\
\text { making meatballs. }\end{array}$ & $\begin{array}{l}\text { Bakso halus (soft meatball) is made } \\
\text { from meat from the upper leg portion } \\
\text { of the cow, and bakso kasar (tendon } \\
\text { meatball) consists of spare beef meat } \\
\text { and tendon. The broth is made with } \\
\text { marrow bones. } \\
\text { Beef is bought from slaughterhouse at } \\
5 \text { am and placed in a plastic container. } \\
\text { A certain brand of tapioca flour in a } \\
\text { plastic package of } 250 \text { gr is used. }\end{array}$ & $\begin{array}{l}\text { The use of pre-rigor beef is highly } \\
\text { recommended. Also, the meat } \\
\text { should be fat-free and connective } \\
\text { tissue-free, and come from certain } \\
\text { beef cuts such as round, chuck, } \\
\text { brisket, topside, rump, and } \\
\text { silverside } \\
\text { Meat should be fresh. }\end{array}$ \\
\hline $\begin{array}{ll}\text { Raw } & \text { Material } \\
\text { Storage } & \end{array}$ & $\begin{array}{l}\text { Storage room has enough ventilation } \\
\text { and light. } \\
\text { Raw meat is placed in a chiller. Beef } \\
\text { skin and rotten parts are removed. } \\
\text { Dry and wet ingredients are separated. }\end{array}$ & $\begin{array}{l}\text { There is a storeroom for dry } \\
\text { ingredients. However, meat and other } \\
\text { wet ingredients are processed right } \\
\text { away within } 30 \text { minutes of arriving. }\end{array}$ & $\begin{array}{l}\text { There should be a separate } \\
\text { storeroom for dry and wet } \\
\text { ingredients. Even though meat is } \\
\text { bought every day, a chiller is } \\
\text { essential to store meat for2- } 4 \\
\text { hours, or a freezer for long- } \\
\text { term storage. }\end{array}$ \\
\hline Meat Processing & $\begin{array}{l}\text { Meat is processed from } 5.00-8.00 \text { in the } \\
\text { morning. Material composition: } \\
\text { beef:flour;ice=66,7:13.3:20. } \\
\text { processing procedure is as follows: }\end{array}$ & $\begin{array}{l}\text { Meat is processed from } 5.30-8.00 \text { am. } \\
\text { Material composition: } \\
\text { beef:flour;ice=80 :10 :10. The } \\
\text { processing procedure is as follows: }\end{array}$ & $\begin{array}{l}\text { According to Koswara [23], } \\
\text { meatball production principally } \\
\text { consists of four stages, i.e. (1) } \\
\text { meat grinding, (2) meat batter } \\
\text { mixing, (3) meatball shaping, and } \\
\text { (4) boiling. }\end{array}$ \\
\hline
\end{tabular}




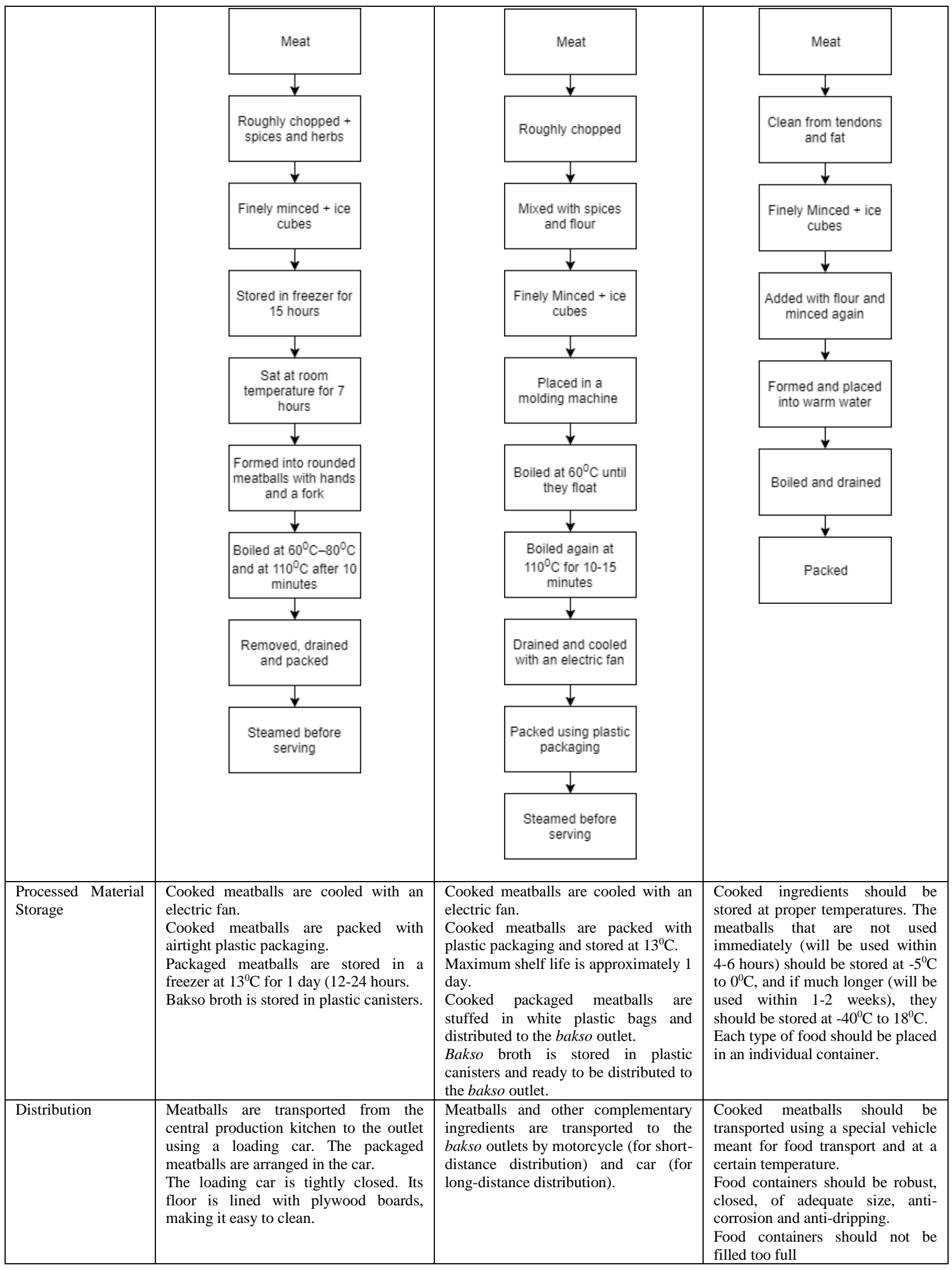




\begin{tabular}{|c|c|c|c|}
\hline Presentation & $\begin{array}{l}\text { Meatballs are arranged in a glass } \\
\text { cabinet. There are two cabinets, one for } \\
\text { display and the other one for storage and } \\
\text { warmer. The meatballs are always kept } \\
\text { on warm at } 60^{\circ} \text { until ready to serve. } \\
\text { Serving equipment such as bowls, } \\
\text { spoons and forks are provided in limited } \\
\text { quantities. Thus, the dishes are } \\
\text { immediately washed. } \\
\text { Meatballs and other ingredients are } \\
\text { stored in open self-service display } \\
\text { cabinets. Broth is poured into the } \\
\text { customer's bowl by the seller. }\end{array}$ & $\begin{array}{l}\text { Meatballs and other complementary } \\
\text { ingredients are immediately arranged } \\
\text { in a display cabinet, and some of them } \\
\text { are heated in a pot at a temperature } \\
\text { above } 60^{\circ} \mathrm{C} \text {. A bowl of bakso is served } \\
\text { hot. } \\
\text { Serving equipment such as bowls, } \\
\text { spoons and forks are provided in } \\
\text { limited quantities. Thus, the dishes are } \\
\text { immediately washed. } \\
\text { Restaurant applies a manual ordering } \\
\text { system. Customers go to the counter, } \\
\text { place their order, pay for their food, } \\
\text { and a bowl of hot bakso is served on } \\
\text { the table by the restaurant staff. }\end{array}$ & $\begin{array}{l}\text { Serving bowls should be durable, } \\
\text { heat-resistant and non- } \\
\text { contaminating. } \\
\text { Meatballs and other ingredients are } \\
\text { served in clean, safe and non-toxic } \\
\text { dish set. } \\
\text { Food temperature before being } \\
\text { placed in a food warmer should be } \\
\text { above } 60^{\circ} \mathrm{C} \text {. The best utensil for } \\
\text { maintaining the serving } \\
\text { temperature is a bean merry. }\end{array}$ \\
\hline
\end{tabular}

The raw materials used in the two bakso restaurants in Malang city are pre-rigor meat cuts namely silverside and upper leg section. As stated by Ayustaningwarno [24], meat used for producing meatballs should be fat-free and connective tissue-free, and come from certain beef cuts such as round, chuck, topside, rump, outside, and silver side. Also, the meat should be fresh. Pre-rigor meat is a meat suitable for use in the production of meatballs because its salt-soluble protein extraction can reach $50 \%$, making the amount of fat emulsified by protein from pre-rigor meat is higher than that by protein from post-rigour meat [25]. Raw materials greatly determine the quality and nutrient content in processed meatballs. The main ingredient in the production of bakso Malang is beef. It is recommended to use fresh or pre-rigor beef to produce chewy and compact meatballs. According to Minantyo [26], goodquality beef has a little odour (normal smell without rotten odour), tender and elastic texture, is not slimy, not dry, and not pale (bright red colour). The beef used to make meatballs should be the freshest meat possible, which is obtained immediately after the slaughter of the animal.

The fillers used to make meatballs are tapioca flour mixed with sago flour. These fillers serve to repair and stabilise the emulsion, increase water absorption capacity, minimise shrinkage, increase product weight and reduce production cost [27]. The high starch content in tapioca flour makes this filler able to bind water but cannot emulsify fat. Starch in hot water can form a thick gel. Starch consists of two inseparable fractions, namely amylose and amylopectin. Amylose is hygroscopic (easy to absorb water), so it is easy to form a gel. The proportion of amylose and amylopectin in starch determines the characteristics of processed products; the lower the amylose content, the higher the viscosity of the processed product. Nevertheless, to produce good-quality meatballs, the maximum amount of tapioca flour should be 50\% [27]. The more tapioca flour is added, the less the elasticity of the meatballs and the lower the protein content is. It is because the meatballs contain less meat but high carbohydrate.

Tapioca flour also called cassava starch consists of carbohydrate granules, is white and odourless, and has no sweet taste. In meatballs, tapioca starch serves to repair and stabilise emulsion, increase water holding capacity, minimise shrinkage, increase volume, and improve the texture of meatballs [24].
The meatball production in the two restaurants has fairly complied with the procedural requirements. The meat mixture consisted of $70 \%$ meat $20 \%$ tapioca flour, and $10 \%$ ice water and other spices; it is a fairly balanced composition. The meat was first roughly chopped, then minced/ground and added with flour, spices, and ice cubes. After that, all the ingredients were mixed thoroughly. The mixture was allowed to sit, formed, placed into warm water, and boiled for about 15 minutes.

The meat-grinding process aims to break the meat fibres and facilitate the stirring process so that the protein soluble in the salt solution can easily come out [25]. Moreover, the purpose of the addition of ice cubes is to form gel/gelatin naturally; without ice cube, protein denaturation may occur. Ice cube plays a role to keep meat mixture at a low temperature. Also, it serves to dissolve salt and spread it evenly throughout the meat mass, facilitate protein extraction from meat, and assist in the formation of emulsions. Heinz \& Hautzinger and Usmiati further explained that the addition of ice cubes during grinding can affect the texture of meatballs and aims to 1) dissolve salt and distribute it evenly, 2) facilitate protein extraction from muscle fibres, 3) keep the temperature of the meat mixture temperature low, 4) assist the formation of the emulsion [28], [29].

The two restaurants used plastic canisters to store the meatball broth and this not recommended even though the broth has cooled. Plastic canisters and plastic scoops contain plastic monomers which are hazardous substances that can contaminate the broth. The broth of Bakso is hot and contains lots of fat. Plastic monomers are formed if the fat content of food is high and at a high temperature. The container used for food storage should have a lid. In accordance with the Regulation of the Minister of Health of the Republic of Indonesia No. 1096 / MENKES / PER / VI / 2011 on Sanitary Hygiene of Food and Beverage Service in the attachment of good manufacturing practices (CPMB) [30], containers used for storing cooked food shall be covered by a properly fitting ajar lid that can release hot steam to prevent condensation.

Nutritional content of meatballs is suitable for microbial growth so that beef meatballs have a relatively short shelf life. The maximum shelf life of meatballs is approximately 1 day (12-24 hours), and one way to prolong the shelf life is by storing them at low temperatures. This strategy has been done by the two restaurants of bakso Malang; they keep the meatballs in the freezer before being distributed and served to the customers. 
Not all types of cooked food are consumed directly, especially food that comes from catering services such as meatballs. Food that is placed at room temperature over 4 hours has a risk of bacteriological contamination. The Regulation of the Minister of Health of the Republic of Indonesia No. 1096 / MENKES / PER / VI / 2011 on Sanitary Hygiene of Food and Beverage Service stated that containers used for storing cooked food shall be covered by a properly fitting ajar lid that can release hot steam to prevent condensation and food shall be separated according to its type. Storing meatballs can be done by: 1) packing meatballs that have cooled using securely closed plastic containers 2) storing them in a chiller (meatballs can last up to 5 days) 3) putting them into a freezer after being stored in airtight containers (meatballs can last up to 1 month).

The transport of cooked meatballs from the production kitchen to the restaurant should be done properly, as contamination may occur due to transport units or containers which do not meet the standards. According to the Regulation of the Minister of Health of the Republic of Indonesia No. 1096 / MENKES / PER / VI / 2011 on the requirements for food transport, food products should be distributed using special vehicles for food transport, be kept in a strong and closed container at appropriate temperatures $\left(60^{\circ} \mathrm{C}\right.$ for hot foods, and $4^{\circ} \mathrm{C}$ for cold foods), not be stacked on top of each other, and not be transported for long periods. Sawong, Andrias, \& Muniroh [31], explained that the transport of cooked food should take the following matters into account: 1) each type of food should be placed in an individual container; 2) food containers should not be filled too full; 3) food containers should be robust, of adequate size, anti-corrosion and anti-dripping; and 4) vehicles should be meant only for food transport, not for other purposes.

In serving bakso, the meatballs and broth in the pot should not be heated at temperatures above $80^{\circ} \mathrm{C}$. A long duration of heating can cause an increase in the amount of water absorbed because the water content can diffuse into the meatballs and bind to starch and protein. The overheating treatment causes a loss of starch granule structure so that water enters the granular structure.The longer the heating process, the easier the water enters the starch granules [32]. Starch binds water due to the presence of hydroxyl groups capable of absorbing much water.

All in all, implementing the HACCP method is a viable solution to produce healthy and safe meatball products and eventually overcome food safety issues that cause harm to human health.

\section{CONCLusions}

The results of the research on the two popular bakso restaurants in Malang city, Indonesia have led us to the following conclusions. 1) The raw materials are fairly wellselected, e.g. the use of pre-rigor beef. However, microbiological and physical contamination might occur when the meat is purchased and placed in a container containing contaminants, and also during the production process. 2) The meat is not stored in a proper storeroom before being processed; the meat is left out at room temperature for 4-5 hours, and it can be contaminated. 3) The entire meatball processing - from the meat is chopped until the cooked meatballs are stored - has complied with the proper procedure. The material formulation is also in accordance with SNI. However, the process of shaping the meatballs manually (using hands and spoons) can cause microbiology contamination. Moreover, it is also possible for dust particles to adhere to the meatballs when they are cooled using an electric fan. 4) The storage of meatballs in the chiller at a certain temperature, the use of plastic canisters to store the broth of bakso, and the transport of bakso products from the production kitchen to the restaurant are critical aspects that need to be identified further. 5) Before serving, the meatballs and other ingredients are stored in a glass display cabinet at room temperature; this might also cause microbiological and physical contamination. As a follow up to this research, the researchers are planning to perform further studies in accordance with the HACCP Method, i.e. analysis of hazards, identification of the Critical Control Points, and other steps up to the documentation stage.

\section{REFERENCE}

[1] F. Margaret, Margaret Fulton Encyclopedia Of Food And Cookery. Octopus Books Pty Ltd, 1983.

[2] B. Dương and M. Kiesel, The simple art of Vietnamese cooking. Melnourne: Prentice Hall Press, 1991.

[3] V. R. Redden and T. Chen, "The potential of Chinese meatballs and dried meat as value added PSE pork products," Food Aust., vol. 47, no. 7, pp. 323-326, 1995.

[4] M. Serdaroğlu and Ö. Değırmencioğlu, "Effects of fat level (5\%, 10\%, $20 \%)$ and corn flour $(0 \%, 2 \%, 4 \%)$ on some properties of Turkish type meatballs (koefte)," Meat Sci., vol. 68, no. 2, pp. 291-296, 2004.

[5] T. Garnett, S. Mathewson, P. Angelidas, and F. Borthwick, "Policies and actions to shift eating patterns: What works? A review of the evidence of the effectiveness of interventions aimed at shifting diets in more sustainable and healthy directions.," 2015.

[6] K. G. Grunert and J. M. Wills, "A review of European research on consumer response to nutrition information on food labels," J. Public Health (Bangkok)., vol. 15, no. 5, pp. 385-399, 2007.

[7] A. C. Hoek, D. Pearson, S. W. James, M. A. Lawrence, and S. Friel, "Healthy and environmentally sustainable food choices: Consumer responses to point-of-purchase actions," Food Qual. Prefer., vol. 58, pp. 94-106, 2017.

[8] L. Panjaitan, "Pemeriksaan dan penetapan kadar boraks dalam bakso di Kota Madya Medan," Universitas Sumatra Utara, 2010.

[9] S. Hikmawati, "Studi kandungan boraks pada makanan jajanan bakso yang beredar di pasar di wilayah Kodia Semarang," Diponegoro University, 2009.

[10] Teddy, "Pengaruh Konsentrasi Formalin Terhadap Keawetan Bakso Dan Cara Pengolahan Bakso Terhadap Residu Formalinnya," Institut Pertanian Bogor, 2007.

[11] E. Council, "COUNCIL DIRECTIVE 93/42/EEC concerning medical devices," Off. J. Eur. Communities, Luxemb., 1993.

[12] S. Leaper, "HACCP: A practical guide Technical, Manual No. 38." Campden Food and Drink Research Association, Chipping Campden, Gloucestershire, 1992.

[13] J. E. Ehiri, G. P. Morris, and J. McEwen, "Implementation of HACCP in food businesses: the way ahead," Food Control, vol. 6, no. 6, pp. 341345, 1995.

[14] J. E. Pardo et al., "Application of hazard analysis and critical control points (HACCP) to the cultivation line of mushroom and other cultivated edible fungi," Indian J. Microbiol., vol. 53, no. 3, pp. 359369, 2013. 
[15] D. P. Kafetzopoulos, E. L. Psomas, and P. D. Kafetzopoulos, "Measuring the effectiveness of the HACCP food safety management system," Food Control, vol. 33, no. 2, pp. 505-513, 2013.

[16] L. Meng, Q. Yang, and J. Cheng, "Study on the application of HACCP system in ice-cream premix powder processing," J Anhui Agric Sci, vol. 39, pp. 6531-6533, 2011.

[17] M. Thompson, G. Sylvia, and M. T. Morrissey, "Seafood traceability in the United States: Current trends, system design, and potential applications," Compr. Rev. food Sci. food Saf., vol. 4, no. 1, pp. 1-7, 2005.

[18] M. Mac Takahashi and K. Yamashita, "Clean and safe supply of fish and shellfish to clear the HACCP regulation by use of clean and cold deep ocean water in Rausu, Hokkaido, Japan," J. Ocean Univ. China. JOUC, vol. 4, no. 3, p. 219, 2005.

[19] M. El-Hofi, E.-S. El-Tanboly, and A. Ismail, "Implementation of the Hazard Analysis Critical Control Point (HACCP) system to UF white cheese production line," Acta Sci. Pol. Technol. Aliment., vol. 9, no. 3, pp. 331-342, 2010.

[20] M. Kassem, E. Salem, A. M. Ahwal, M. Saddik, and N. F. Gomaa, "Application of hazard analysis and critical control point system in the dairy industry," La Rev. Sante la Mediterr. Orient., vol. 8, no. 1, pp. 114-128, 2002.

[21] E. N. Kokkinakis, G. A. Fragkiadakis, S. H. Ioakeimidi, I. B. Giankoulof, and A. N. Kokkinaki, "Microbiological quality of ice cream after HACCP implementation: a factory case study," Czech J. Food Sci. (Czech Republic), vol. 26, no. 5, pp. 383-391, 2008.

[22] D. Wang et al., "Application of hazard analysis critical control points (HACCP) system to vacuum-packed sauced pork in Chinese food corporations," Food Control, vol. 21, no. 4, pp. 584-591, 2010.

[23] S. Koswara, "Teknologi Praktis Pengolahan Daging e-Book," 2009. [Online]. Available: http://tekpan.unimus.ac.id/wp- content/uploads/2013/07/teknologi-praktis-pengolahan-daging.pdf. [Accessed: 06-Mar-2017].

[24] F. Ayustaningwarno, Teknologi Pangan; Teori Praktis dan Aplikasi. Yogyakarta: Graha Ilmu, 2014.

[25] Soeparno, Ilmu dan Teknologi Daging, 4th ed. Yogyakarta: Gadjah Mada University Press, 2005.

[26] H. Minantyo, DASAR -DASAR PENGOLAHAN MAKANAN (Food Product Fundamental). Yogyakarta: Graha Ilmu, 2011.

[27] Y. N. Shariffa, A. A. Karim, A. Fazilah, and I. S. M. Zaidul, "Enzymatic hydrolysis of granular native and mildly heat-treated tapioca and sweet potato starches at sub-gelatinization temperature," Food Hydrocoll., vol. 23, no. 2, pp. 434-440, 2009.

[28] G. Heinz and P. Hautzinger, Meat processing technology for small to medium scale producers. FAO, 2009.

[29] S. Usmiati, "Pengawetan daging segar dan olahan,” Bogor, 2010.

[30] Menteri Kesehatan Republik Indonesia, Peraturan Menteri Kesehatan Republik Indonesia Nomor 1096/MENKES/PER/VI/2011. Indonesia: http://kesmas.kemkes.go.id/perpu/konten/permenkes/pmk-nomor-1096tahun-2011-tentang-higiene-sanitasi-jasaboga, 2011.

[31] K. S. A. Sawong, D. R. Andrias, and L. Muniroh, "Penerapan Higiene Sanitasi Jasa Boga Pada Katering Golongan A2 dan Golongan A3 di Kota Palangka Raya Provinsi Kalimantan Tengah," Media Gizi Indones., vol. 11, no. 1, pp. 1-10, 2016.

[32] V. Vaclavik and E. W. Christian, Essentials of Food Science, 3rd ed. New York: Springer, 2008. 